\title{
Potret Kekristenan Pada Suku Dayak Pesaguan Di Provinsi Kalimantan Barat
}

\author{
Tio Pilus Arisandie \\ Sekolah Tinggi Theologia Baptis Indonesia (STBI) Semarang \\ arisandiegumay@stbi.ac.id
}

\begin{abstract}
The Pesaguan Dayak tribe is a tribe in West Kalimantan Province. Most of the people of this tribe are Catholic and Protestant. In the initial observation (pre-research), it seems that their understanding of the Bible and its position in the practice of life needs attention. However, in everyday life, the Pesaguan Dayak community is still robust with the customs, ethics, and moral norms of the tribal religion. To obtain a Christian portrait of the Pasaguan Dayak tribe, the researchers used qualitative research methods, emphasizing surveys or observations and interviews. From the results of research and interviews conducted, it was found that in the daily life of the Pesaguan Dayak people, the Bible is not the primary basis for the Pesaguan Dayak tribe. Another portrait of Christianity found in the field is the absence of awareness from the Pesaguan Dayak community to reach out to Malays to believe in Jesus, even though they live next door.
\end{abstract}

Keywords: dayak pasaguan; christianity; ethnography

\begin{abstract}
Abstrak
Suku Dayak Pesaguan adalah suku yang berada di Provinsi Kalimantan Barat. Sebagian besar orang-orang dari suku ini beragama Katolik dan Protestan. Pada obersevasi awal (prapenelitian), tampaknya pemahaman mereka tentang Alkitab dan posisinya dalam praktik kehidupan, perlu mendapat perhatian. Dalam kehidupan sehari-hari, masyarakat suku Dayak Pesaguan masih sangat kuat dengan adat istiadat, etika dan norma-norma moral agama suku. Untuk memperoleh potret kekristenan suku Dayak Pasaguan, maka peneliti memanfaatkan metode penelitian kualitatif, dengan menekankan pada survei atau observasi dan wawancara. Dari hasil penelitian dan wawancara yang dilakukan, ditemukan bahwa dalam kehidupan sehari-hari masyarakat suku Dayak Pesaguan, Alkitab bukanlah landasan dasar utama yang dimiliki suku Dayak Pesaguan. Potret kekristenan lainya yang ditemukan di lapangan yaitu belum adanya kesadaran dari masyarakat suku Dayak Pesaguan untuk menjangkau orang Melayu untuk percaya pada Yesus, meskipun mereka hidup bertetangga.
\end{abstract}

Kata Kunci: dayak pasaguan; kekristenan; etnografi 


\section{Pendahuluan}

Bangsa Indonesia terdiri dari banyak pulau akan tetapi dari sekian banyak pulau di Indonesia, yang paling menonjol ada lima pulau besar yaitu Sumatra, Jawa, Kalimantan, Sulawesi, dan Irian Jaya. Selain pulau-pulau yang besar tersebut, ada juga pulau-pulau kecil lainnya yang bertebaran dari Sabang sampai Merauke. Dari keanekaragaman budaya, suku dan bahasa daerah yang ada, bangsa Indonesia memiliki alat pemersatu yaitu bahasa Indonesia yang berasal dari bahasa Melayu. Walaupun pada kenyataannya bangsa Indonesia tetap saja memiliki banyak perbedaan satu dengan lainnya, misalnya perbedaan suku, bahasa daerah, lokasi, lingkungan, budaya serta masih banyak perbedaan lainnya.

Perbedaan-perbedaan ini menjadi sebuah karakter yang khas dari Bangsa Indonesia. Jika dilihat dari sudut pandang Alkitab, Tuhan Allah yang menciptakan manusia dalam dunia ini. Allah menciptakan manusia untuk menjadi obyek kasih-Nya. Akan tetapi karena pelanggaran dan ketidaktaatan manusia, maka hubungan yang baik antara Allah dengan manusia terputus. Berkaitan dengan hal tersebut, Wilayah Pulau Kalimantan juga terdiri dari berbagai suku yang memiliki banyak perbedaan, baik dalam bahasa maupun adat istiadat. Namun demikian, setiap suku memiliki peranan penting dalam membangun kehidupan setiap sukunya masing-masing. Pada umumnya orang-orang Dayak sudah mengenal Tuhan Yesus, akan tetapi banyak di antara mereka hanya mengenal saja tetapi aplikasi dari ajaran tersebut masih sangat kurang dilakukan oleh masyarakat pada umumnya. Salah satu contoh di antaranya yaitu masih kuatnya okultisme dan sinkritisme. ${ }^{1}$

Pulau Kalimantan terdiri dari empat Provinsi, yaitu Provinsi Kalimantan Barat, Kalimantan Tengah, Kalimantan Selatan, dan Kalimantan Timur. Dalam setiap Provinsinya dihuni oleh ratusan suku yang salah satu diantaranya adalah suku Dayak. Suku Dayak merupakan suku terbesar dan paling dikenal di wilayah Provinsi Kalimantan Barat. Dalam suku Dayak terbagi lagi dalam struktur suku-suku yang lebih kecil dan salah satu diantaranya adalah suku Dayak Pesaguan yang terletak di sekitar aliran sungai Pesaguan. Sungai Pesaguan terletak di Kecamatan Tumbang Titi, Kabupaten Ketapang, Provinsi Kalimantan Barat. ${ }^{2}$

Suku Dayak Pesaguan satu rumpun dengan suku Dayak Kayung yang terletak tidak jauh dari sekitar sungai Pesaguan. Banyak hal yang menarik untuk dipelajari dari orangorang Dayak Pesaguan yang unik dan menarik, akan tetapi yang terpenting dari itu dapat digunakan sebagai satu sarana dalam menjangkau orang Dayak Pesaguan supaya dapat mengenal Injil dengan benar. ${ }^{3}$

${ }^{1}$ Herianto Herianto et al., "The Plant Wisdom of Dayak Ot Danum, Central Kalimantan," Journal of Tropical Life Science 8, no. 2 (2018): 130-143; Rudy G Erwinsyah et al., "Gereja Dan Transformasi Sosial Dalam Masyarakat Dayak Kualatn Di Hulu Sungai Buayan," Rural Economies 1, no. 2 (2010): 1-26.

${ }^{2}$ Laksmi Kusuma Wardani et al., “Form And Meaning Of Dayak Traditional House In East Kalimantan, Indonesia (Case Study: Lou Pepas Eheng Dayak Benuaq's House)," Advances in Social Science, Education and Humanities Research, volume 207 : 3rd International Conference on Creative Media, Design and Technology (REKA 2018) Form 207, no. Reka (2019): 265-272; Semiarto Purwanto, "Questioning the Development: The Maintenance of Local Variety of Rice in the Changing Dayak Community of Central Kalimantan , Indonesia," Advances in Social Science, Education and Humanities Research (ASSEHR), volume 161 :International Conference on Issues in Social and Education Research (ICISER 2017) Questioning 161, no. Iciser 2017 (2018): 22-26.

${ }^{3}$ Hamid Darmadi, "Sumpit (Blowgun) as Traditional Weapons with Dayak High Protection," JETL (Journal Of Education, Teaching and Learning) 3, no. 1 (2018): 113; Atmaezer Hariara Simanjuntak and Dwi P Sulaksono, "PALM OIL TREE FETISH: A PLANTATION GOD IN THE PROCESS OF CONSTRUCTION IN WEST KALIMANTAN," The 7th International Symposium of Journal Antropologi Indonesia (2019): 145-146; Ferry Hartono, Sukawiti Sukawiti, and Herianus Nuryadi, “Idealized 
Penelitian terdahulu belum mendeskripsikan etnografi suku dayak, hanya bersifat gambaran umum. ${ }^{4}$ Penelitian mengenai kepercayaan asli masyarakat Dayak juga pernah dilaksanakan seperti penelitian. ${ }^{5}$ Selanjutnya, penelitian mengenai karekteristik berburu masyarakat Dayak yang terlihat dalam penggunaan sumpit sebagai senjata tradisional. ${ }^{6}$ Berdasarkan penelitian sebelumnya, lokus Dayak Pesaguan belum ditemukan yang menjelaskan etnografi dan Kekristenen. Penelitian yang berkaitan dengan budaya dan Kekristenen ditemukan dengan lokus yang berbeda, yaitu masyarakat Timor dan Budaya Kerjanya dalam teologia kontekstual. ${ }^{7}$

Untuk lebih banyak mengetahui suku Dayak Pesaguan, maka harus diadakan penelitian, sehingga dapat dengan mudah bisa diterima dalam satu masyarakat atau satu suku tersebut. Penelitian suku dan kebudayaan itu disebut etnografi. ${ }^{8}$ Dewasa ini banyak hamba Tuhan atau utusan Injil yang lebih mengutamakan berbagai metode penginjilan dari pada etnografi. Padahal, etnografi itu sangatlah penting, karena melalui etnografi kita dapat mengetahui bagaimana menggunakan metode yang baik dalam menjangkau masyarakat dari suku tertentu. ${ }^{9}$ Selain itu, pendekatan ini akan menolong para peneliti bisa mengetahui dan mengerti kebudayaan, adat-istiadat, serta cara hidup masyarakat atau suku tersebut. Oleh karena itu, dengan adanya penelitian etnografi, penulis berharap dapat menolong para hamba Tuhan atau utusan Injil yang terbeban atau ingin mengetahui keberadaan suku Dayak Pesaguan di Provinsi Kalimantan Barat.

\section{Metode Penelitian}

Etnografi adalah metodologi yang berdasarkan pada pengamatan langsung. Ketika menggunakan etnografi, penting untuk mendengarkan percakapan narasumber secara langsung, membaca dokumen yang diproduksi oleh organisasi yang diteliti, dan mengajukan pertanyaan komunitas ${ }^{10}$ Namun yang paling membedakan etnografi dari metodologi lain adalah peran yang lebih aktif dalam mengamati, mengamati, melihat, memandang, memandang, dan meneliti. ${ }^{11}$ Etnografi, seperti metodologi lainnya, bukan

Abstraction of the Concept of Human in Dayak Kanayatn's Byword and Its Importance in Dissolving Ethnic Conflicts in West Borneo," Advances in Social Science, Education and Humanities Research, volume 203: International Conference on Life, Innovation, Change, and Knowledge (ICLICK 2018) Idealized 203, no. Iclick 2018 (2019): 62-68.

${ }^{4}$ Ade Ikhsan Kamil, “DARI POHON HIDUP KE KAYU MATI Perubahan Pencarian Keselamatan Orang Dayak Dalam Kehidupan Desa Di Kalimantan Barat," Jurnal Sosiologi USK 12, no. 1 (2018): 76-88.

${ }^{5}$ Hartono et al., (2019)

${ }^{6}$ Darmadi, "Sumpit (Blowgun) as Traditional Weapons with Dayak High Protection."

7 Iswanto and Ferdinand Alexander, "Perspektif Inklusif Pendidikan Agama Kristen Terhadap Teks Kerja Pada Masyarakat Dawan Di Nusa Tengara Timur" 1 (2020): 71-84.

${ }^{8}$ B. Guy Peters, Guillaume Fontaine, and Raul Pacheco-Vega, "Using Ethnography in Comparative Policy Analysis: Premises, Promises and Perils," Handbook of Research Methods and Applications in Comparative Policy Analysis, no. October (2020): 312-332.

9 Kamil, "DARI POHON HIDUP KE KAYU MATI Perubahan Pencarian Keselamatan Orang Dayak Dalam Kehidupan Desa Di Kalimantan Barat."

${ }^{10}$ Doris Lydahl et al., "Doing Data Together - Affective Relations and Mobile Ethnography in Home Visits," Qualitative Research (2020).

${ }^{11}$ Iswanto and Rinto Hasiholan Hutapea, "LEGO-LEGO AS PHENOMENON OF INTERRELIGIOS AND CULTURAL IN ALOR SOCIETY," Harmoni 19, no. 1 (October 28, 2020): 85-99, http://jurnalharmoni.kemenag.go.id/index.php/harmoni/article/view/361. 
sekadar instrumen pengumpulan data. Ia lahir pada saat tertentu dalam sejarah masyarakat dan mewujudkan ciri-ciri budaya tertentu. ${ }^{12}$

Sejak tahun 1980-an makna etnografi telah diperluas sedemikian rupa sehingga mencakup bentuk-bentuk penelitian yang sangat beragam dari sudut pandang metodologis. Secara konkrit etnografi meliputi analisa otobiografi hingga analisis naratif, dari penelitian tindakan hingga kinerja, hingga penelitian lapangan yang berlangsung dari beberapa hari hingga beberapa tahun. James Lull dan David Morley telah menunjukkan bahwa apa yang dianggap sebagai etnografi dalam studi budaya gagal memenuhi persyaratan fundamental untuk pengumpulan dan pelaporan data yang khas dari sebagian besar penelitian etnografi antropologis dan sosiologis. ${ }^{13}$ Untuk itu mereka mengajukan sistematika etnografi yang diperluas secara narasumber, sumber data skunder, dan interpretasi yang kuat. ${ }^{14}$

Metodologi etnografi terdiri dari dua strategi penelitian: observasi non partisipan dan observasi partisipan. Dalam kasus pertama, peneliti mengamati subjek 'dari kejauhan' tanpa berinteraksi dengan mereka. Mereka yang menggunakan strategi ini tidak tertarik untuk menyelidiki bidang simbolik, dan mereka memastikan untuk tidak mengganggu tindakan subjek agar tidak mempengaruhi perilaku mereka. Tentu saja ada beberapa situasi perantara antara dua ekstrem observasi partisipan dan non partisipan. ${ }^{15}$

Penelitian ini akan dilaksanakan di Suku Dayak Pesaguan satu rumpun dengan suku Dayak Kayung yang terletak tidak jauh dari sekitar sungai Pesaguan yang berlokasi di Kecamatan Tumbang Titi, Kabupaten Ketapang, Provinsi Kalimantan Barat. Penelitian dilaksanakan mulai tahun 2010 hingga tahun 2019. Beberapa hasil penelitian dipublikasikan dalam beberapa ranah penelitian meliputi, sosiologi, antropologi, arkeologi, humality, dan teologi. Karena berlangsung cukup lama, penelitian ini sudah mewawancari 60 an narasumber sebagaimana yang dilampirkan pada tabel 1 di bawah ini.

${ }^{12}$ Erica S. Simmons and Nicholas Rush Smith, "The Case for Comparative Ethnography," Comparative Politics 51, no. 3 (2019): 341-359.

${ }^{13}$ Mark De Rond, Isaac Holeman, and Jennifer Howard-Grenville, "Sensemaking from the Body: An Enactive Ethnography of Rowing the Amazon," Academy of Management Journal 62, no. 6 (2019): 1961-1988.

${ }^{14}$ Mirjam Wajsberg, "Following Fatigue, Feeling Fatigue: A Reflexive Ethnography of Emotion," Social Inclusion 8, no. 4 (2020): 126-135.

${ }^{15}$ De Rond, Holeman, and Howard-Grenville, "Sensemaking from the Body: An Enactive Ethnography of Rowing the Amazon." 
Tabel 1. Daftar Narasumber 2010-2019

\begin{tabular}{|c|c|c|}
\hline Nama & Jabatan dalam suku & Umur \\
\hline Yan Sukanda & Peneliti Suku Dayak Pesaguan dalam Musik & 40 \\
\hline Apolus & Mahasiswa ISI penlitian musik Pesaguan & 22 \\
\hline Lukas Asi & Ketua majlis GBIP & 57 \\
\hline Wandi & Guru SD di Dayak Pesaguan & 30 \\
\hline Pdt. Robet & Gembala Sidang GPIB & 35 \\
\hline Tanto & Majelis GPIB & 50 \\
\hline Kiki & Pemudi Dayak Pesaguan & 18 \\
\hline Irfan & Pegawai Pemda Ketapang & 35 \\
\hline Tongkim & Pengajar SMA Antokia Ketapang & 30 \\
\hline Ibu Tongkim & Guru Seni adat Dayak & 35 \\
\hline Rajiin & Sejarahwan Dayak Pesaguan & 57 \\
\hline Oyong & Pegawai Kantor Camat & 37 \\
\hline Pdt. Cang & Gembala Sidang KGBI & 35 \\
\hline Arkalaus & Majelis GPIB & 51 \\
\hline Boy Wan & Pemuda Dayak Pesaguan & 22 \\
\hline $\begin{array}{l}\text { Harun } \\
\text { Mantap }\end{array}$ & Perintis GPIB Serengkah & 60 \\
\hline Ibrahim & Perintis GPIB Nantai Panjang & 58 \\
\hline Kam jun & Printis GBIB & 56 \\
\hline Martin R & $\begin{array}{l}\text { Anggota Perwakilan rayat Seringakah di DPRD } \\
\text { Ketapang }\end{array}$ & 40 \\
\hline Ivo & $\begin{array}{l}\text { Anggota Perwakilan Rayat Natai Panjang di } \\
\text { DPRD Ketapang }\end{array}$ & 30 \\
\hline Yusni & Masyrakat Dayak Pesaguan & 50 \\
\hline Ilik & Domong Adat & 50 \\
\hline Idak & Ketua majelis GBIP Beringin & 45 \\
\hline Edo & Ketua Pemuda Beringin & 22 \\
\hline Alieta & Siswa Dayak di SMA Antokia Ketapang & 18 \\
\hline Erik & Ketua Pemuda Serengkah & 21 \\
\hline Juara & Guru SD Dayak Pesaguan & 46 \\
\hline Jumali & Guru SD Beringin & 40 \\
\hline $\begin{array}{l}\text { Pastor } \\
\text { Waloyo }\end{array}$ & Pemimpin Gereja Katolik & 31 \\
\hline Asuan & Pemudi Tumbang Titi & 21 \\
\hline Celeing & Guru SLTP PGRI Serengkah & 27 \\
\hline Pak Guru & Guru SLTP Negeri Tumbang Titi & 50 \\
\hline Neti & Masyrakat Dayak Pesaguan & 39 \\
\hline Akiong & Masyrakat dayak Pesaguan & 50 \\
\hline Frans R & Camat Tumbang Titi & 40 \\
\hline Doni & Kapaolsek Tumbang Titi & 22 \\
\hline Yanto & Anggota Polisi Tumbang Titi & 28 \\
\hline Ocar & Masyrakat Dayak Pesaguan & 33 \\
\hline Atong & Masyrakat Dayak Pesaguan & 40 \\
\hline Yohanes & Pengurus partai Golkar Serengkah & 50 \\
\hline Somai & Masyrakat Dayak Pesaguan & 40 \\
\hline Danel & Kepala Dusun Beringin & 35 \\
\hline Edi & Kepala Dusun Serengkah & 40 \\
\hline Rembet & Ketua Dewan Adat Dayak Pesaguan & 50 \\
\hline Ali & Masyrakat Suku Dayak Pesaguan & 35 \\
\hline Anna & Masyrakat Suku Dayak Pesaguan & 36 \\
\hline
\end{tabular}




\begin{tabular}{|l|l|c|}
\hline Feni & Pemudi Dayak Pesaguaan & 16 \\
\hline Tatik & Pemudi GPIB Serengkah & 20 \\
\hline Helein & Pemudi Katolik Serengkah & 19 \\
\hline Loren & Masyrakat Dayak Pesaguan & 29 \\
\hline Sarah & Anak-anak Serengkah & 12 \\
\hline Mecail & Masyrakat Batu Bulan & 30 \\
\hline Yusti & Masyrakat Dayak Pesaguan & 18 \\
\hline Arif & Masyrakat Muslim Dayak Pesaguan & 30 \\
\hline M Nur & BPS Tumbang Titi & 30 \\
\hline Lia & Masyarakat Nantai Panjang & 29 \\
\hline Rut & Masyrakay sungai Damat & 18 \\
\hline Akeng & Masyrakat Tumbang Titi & 27 \\
\hline Asong & Masyrakat Tumbang Titi & 35 \\
\hline Asim & Orang Pesaguan yang merantau ke pontianak & 36 \\
\hline Tomas & Pemuda Serengkah Kiri & 22 \\
\hline Lukas & Masyrakat Batu Mas & 55 \\
\hline Winarto & Penjual Keliling dari Jawa & 27 \\
\hline Leo & Ketua Persekutuan Dayak Pesaguan Ketapang & 60 \\
\hline
\end{tabular}

\section{Hasil dan Pembahasan}

Ciri fisik orang Dayak Pesaguan, pada umumnya, tidak jauh berbeda dengan orangorang yang ada di Indonesia, yang mempunyai kulit berwarna sawo matang, memiliki tinggi badan rata-rata $150 \mathrm{~cm}$, dan kebanyakan rambut lurus. Akan tetapi ada satu hal yang paling menonjol dari orang-orang Dayak Pesaguan yaitu hampir seluruh orang Dayak Pesaguan mencoret badan mereka dengan tato yang bergambarkan naga yang melingkar di seluruh badan mereka. Di samping itu, keunikan suku Dayak ini terletak pada perihal kepemilikan rumah tinggal, yang agak berbeda dengan sistem pada Dayak di wilayah Kalimantan lainnya. Untuk yang sudah berkeluarga disebut rumah bosa, yang harus dimiliki bagi mereka yang sudah menikah dan hal itu menjadi kebanggaan tersendiri bagi orang Dayak Pesaguan.

Batas wilayah masyarakat Dayak Pesaguan meliputi Barat, berbatasan dengan hutan Kalimantan Tengah. Utara, berbatasan dengan suku Melayu Tumbang Titi. Selatan, berbatasan dengan perbukitan Tumbang Titi Timur, berbatasan dengan hutan lindung milik Pemerintah Bahasa. Masyarakat Dayak Pesaguan menggunakan bahasa Dayak Pesaguan dengan dua dealik yang banyak menggunakan fonim "o" dan "a."

\section{Hasil Penelitian}

Corak kekeluargaan bagi Masyarakat Suku Dayak Pesaguan adalah keluarga besar di mana ada sebutan-sebuatan bagi satu keluarga dan ada keluarga besar dan itu dilakukan dengan perkumpulan keluarga besar diadakan setahun sekali biasanya bertepatan dengan hari natal dimana semua keluarga berkumpul dan bertemu, dan saling menunjukan rasa perhatiannya satu dengan yang lain dengan ketentuan yang lebih muda menghormati yang lebih tua. Dalam pernikahan, masyarakat Dayak pesaguan mengenal beberapa urutan untuk menuju jenjang pernikahan tersebut: (1) Perkenalan, Dimana sang pemuda dan pemudi ini saling mengenal terlebih dahulu, sehingga keduannya saling menyukai dan jika hal itu sudah, dan dengan kesepakatan bersama mereka membicarakannya kepada orang tua masing-masing. (2) Pertunangan, Dan jika kedua orang tua saling menyetujui maka orang tua laki-laki akan datang ke orang tua pihak perempuan menyatakan ingin meminang anak Perempuannya, dan jika orang tua pihak perempuan menyetujuinya dan disaksikan oleh ketua adat (Demong adat), maka mereka melakukan pertunangan. Dan yang unik dari pertunangan ini yaitu kedua calon pengantin yang sudah bertunangan ini sudah 
diperbolehkan tidur satu kasur atau tikar, akan tetapi tidak boleh sampai hamil jika hamil maka keduannya akan mendapatkan hukuman adat yang sangat berat, artinya keduannya boleh tidur satu tikar akan tetapi belum boleh melakukan hubungan layaknya suami istri. Selanjutnya dilanjutkan dengan tahapan (3) Pernikahan, Dalam pernikahan biasanya kedua belah pihak telah menyetujui kesepakatan yang telah ditentukan secara bersama-sama termasuk siapa yang akan mengadakan acara dan hari apa dilaksanakan pernikahnnya itu, dan pada hari akhirnya mereka melakukan pernikahan, ada dua kali pernikahan yang di lakukan oleh masyarakat suku Dayak Pesaguan yang pertama yaitu pernikahan secara adat dimana dalam pernikahan ini ketua adat (Domiong) yang memimpin pernikahan serta membuat penyelusuran jika dalam pernikahan tersebut ditemukan hubungan kekeluargaan maka kedua belah pihak akan mendapatkan hukuman tergantung dengan ketua adat (Domong) yang menentukan hukuman, dan kedua belah pihak harus mandi disungai pesaguan pada waktu tengah malam untuk membersihkan diri, dan dalam pernikahan itu juga ditentukan hukuman dan perjanjian jika keduabelah pihak nantinya akan bercerai maka keduanya akan membayar janji yang diucapkan waktu pernikahan.

Ritual pernikahan biasanya di lakukan dengan pemandian darah kepada kedua belah pihak, jika kedua nya dalam menyelusuran ternyata ada hubungan anak dan Bapak contoh dalam penyelusuran yang panjang ternyata yang perempuan itu harusnya disebut Bibi maka kedua belah pihak akan melakukan ritual maka seperti anjing, dan juga melakukan gerakan-gerakan menyerupai anjing, walaupun keduanya dulunya tidak saling mengenal, akan tetapi justru pernikahan dengan sepupu itu lebih baik karena supaya tetap menjalin dan menjaga harta keluarga, dengan ketentuan pihak laki-laki adalah anak lebih tua dari keluarga tersebut, pernikahan ini tidak diakui oleh negara akan tetapi sah dimata hukum adat Dayak Pesaguan. Kedua, pernikahan Gereja, pernikahan ini bisa dilakukan di Gereja dan dipimpin oleh pastor atau Pendeta yang ada, orang-orang Dayak Pesaguan menginginkan pernikahan ini supaya mereka mendapatkan pengakuan dari pemerintah dan mereka diakui oleh pemerintah.

Lebih lanjut, pembahasan hasil temuan penelitian berkaitan dengan Stratifikasi Sosial. Stratifikasi sosial bagi Masyarakat suku Dayak Pesaguan tidak terlalu menonjol karena kehidupan masyarakat rata-rata bekerja sebagai petani dan pedagang. Mereka tidak mengenal istilah keturunan "Darah Biru" karena tidak berlatar belakang kerajaan atau feodalisme. Namun demikian status pemimpin atau yang dikenal dengan Domong adat adalah orang yang harus dihargai dan dihormati. Jadi kalau bertemu dengan mereka harus menunjukan sifat hormat. Pemimpin dan orang-orang terpandang sangat disegani dan dihormati bagi masyarakat Suku Dayak Pesaguan.

Organisasi sosial dalam masyarakat suku Dayak Pesaguan adalah Dewan adat yang bisa sejajar dengan Bupati dan dewan adat ini mendapat Surat Keputusan dari Gubernur sebagai pemimpin adat Suku Dayak Pesaguan dan dibawahnya itu ada domong-domong adat yang memimpin desa dibidang hukum adat dan ia lebih tinggi dari kepala desa yang berhubungan dengan pemerintahan dan kepala desa ini terdiri dari kepala dusun-dusun dan kepala dusun ini terdiri dari Rukun tetangga.

Pimpinan tertinggi orang Dayak Pesaguan adalah Dewan Tertinggi Pertimbangan Adat dimana dewan ini dipimpin oleh satu orang yang dianggap lebih tua dan bijaksana serta memiliki tutur kata yang baik serta mengerti dan memahami setiap penduduk Dayak Pesaguan, katua adat dipilih oleh penduduk Dayak Pesaguan secara langsung melalui pertemuan yang dihadiri oleh setiap penduduk Dayak Pesaguan serta yang terpilih akan menjalankan tugasnya seumur hidup tanpa ada pergantian jika ia masih hidup dan harus tinggal di rumah adat yang sudah dibangun secara bersama oleh penduduk Dayak Pesaguan. Dewan adat ini di bawahnya ada ketua adat yang memimpin setiap kampung yang ada dan yang mengatur adat dan hukum adat yang ada di masyarakatnya akan tetapi 
di kampung tersebut juga ada kepala desa, kepala dusun yang berurusan dengan pemerintah dan berhubungan dengan Camat, jadi sistem pemerintahan dibedakan dengan sestem adat, akan tetapi keduanya berjalan secara bersamaan dan memimpin kedua organisasi yang berbeda ini sama-sama di hormati oleh penduduknya akan tetapi yang paling menonjol adalah organisasi adat. Salah satu contoh, ketua adat bisa mengatur masalah pemerintahan sehingga pihak pemerintahan tidak bisa mengambil keputusan tanpa pertimbangan adat.

Sistem Peradilan yang dimiliki oleh orang-orang Dayak Pesaguan adalah sistem peradilan musyawarah, jika seorang Dayak Pesaguan melakukan pertemuan dilakukan oleh penduduk yang bersalah serta diikuti oleh ketua adat, camat, ketua kampung, Tumenggung, kalau bisa polisi. Akan tetapi setiap keputusan harus melalui ketua adat yang menentukan hukuman atau sangsi yang harus di ikuti bagi yang bersalah atau membayar denda berupa guci, tajau, atau piring yang putih. Hukuman di bayar kepada ketua adat, akan tetapi jika kesalahannya terlalu besar maka hukumannya dengan cara membayar kepada seluruh penduduk Dayak Pesaguan yang ada, hal itu tinggal kebijaksananan ketua adat dan dewan pertimbangan adat. Keputusan mereka tidak bisa di salahkan dan tidak bolah dipengaruhi oleh pihak manapun, intinya sangsi diberikan oleh ketua adat apa yang akan menjadi keputusannya itulah hukuman bagi orang yang bersalah.

Masyarakat Dayak Pesaguan pada umumnya memiliki hukum sendiri yang mana hukum itu diatur oleh Dewan adat atau ketua adat jika seorang melanggar hukum maka dewan adatlah yang menentukan hukuman dimana dewan adat ini diketuai oleh Domang adat atau ketua adat yang ditentukan oleh masyarakat Dayak Pesaguan dimana ketua adat ini memiliki kriteria sesuai dengan kriteria mereka sendiri dan dilihat dari cara hidupnya serta kebijaksanannya dalam kehidupan sehari-hari. Jadi, hukum yang dimiliki oleh Penduduk Dayak Pesaguan adalah hukum adat-Istiadat yang diketuai oleh Domong adat yang ada, dan inilah norma-norma yang berlaku juga dalam kehidupan sehari-hari.

Berkaitan dengan hal tersebut di atas, jika terjadi kesalah pahaman antara perseorangan maupun kelompok, maka ketua adat berhak menghukum mereka yang bermasalah, jika dalam ketua adat tidak bisa selesai maka ketua adat berhak membawa mereka yang bermasalah ini kehadapan dewan adat dan diputuskan bersama-sama dengan ketua adat dan pembantu adat yang lain, dan tentunya bagi mereka yang bermasalah akan dikenakan hukuman sesuai ketentuan adat yang disampaikan oleh pemuka adat.

Bagi suku Dayak Pesaguan musim buah bukanlah hal yang biasa. Apalagi pada saat hasil panen melimpah, biasanya masyarakat Dayak Pesaguan mewujudkannya dengan melakukan rangkaian upacara adat. Masyarakat Dayak Pesaguan di Kabupaten Ketapang melakuakn ritual itu dengan tujuh rangkaian ritual upacara adat buah-galau (buah-buahan). Ketujuh upacara adat buah tersebut lazimnya dilakuakn pada setiap musim buah raya. Musim buah raya tersebut ditandai dengan berbuahnya beberapa jenis buah seperti kelampai, kumpang, limat (janta) dan kekalak. Rangkaian ini biasanya dipimpin oleh seorang belian (bolin) bauah. Upacara adat buah dimulai dari "memorum doun memangkah dohan" pada saat kuntum mulai tumbuh.

Usai upacara adat ini, masyarakat tidak bolah memanjat pohon durian dan mengambilnya di malam hari. Ini sudah ketentuan seorang belian buah yang memulai acara ini pada waktu musim buah. Mereka tidak boleh makan buah apa pun kecuali hanya boleh makan pinang dan sirih saja. upacara nyabit buah atau "ninjangan senggayung" ini disebut juga sebagai "merimbang bunga" atau memelihara kembang.

Setelah itu diadakanlah saat kembang mulai jadi buah (biasanya berpatokan pada pohon durian) diadakan upacara adat "menimang/memandian pansai." Upacara ini disertai dengan ritual "ma-alap senggayung" (dimana alat musik dari bambu mulai digunakan dalam memetik buah kedalam hutan dan pekarangan) 
Upacara lainnya yang masih dilakukan ialah tuntobus. Acara tuntobus dilakukan sebagai peringatan pergantian tahun orang Dayak Pesaguan. Mereka memiliki Tahun baru sendiri yaitu antara bulan Mei dan Juni, dimana masyarakat habis panen dan minta restu kepada Tuhan supaya mereka memulai berladang kembali. Upacara ini dipimpin oleh ketua adat dan dilakuan di setiap kampung masing-masing dengan minuman arak dan potong babi. Biaya Babi dihasilkan dari pengumpulan dana masyarakat, untuk tuak dan arak mereka membawa masing-masing dari rumah.

Selain itu beberapa upacara adat masih tetap dilakukan seperti Kepercayan Kematian (Nganjan). Orang Dayak Pesaguan memiliki kepercayaan terhadap kematian sebagai sesuatu yang sangat sakral bahkan hal itu lebih sakral dari pada pernikahan. Untuk itu masyarakat Pesaguan mengenal beberapa macam upacara yang berhubungan dengan upacara kematian. Dalam kepercayaan Pesaguan, setelah seseorang meninggal dunia, jiwanya akan menuju ketempat yang dinamakan "ebayan tujuh seruga dalam" mereka yakin bahwa tempat itu yang harus dituju oleh setiap orang yang meninggal, untuk menuju itu maka kerabat yang masih hidup harus melakukan beberapa ritual atau aturan yang ditentukan oleh adat. Karena orang Dayak Pesaguan percaya jika orang mati itu kalau belum di adatkan yang disebut "nganjan" maka orang tersebut Rohnya masih melayang. Pada saat upacara "nganjan" inilah perpisahan antara Roh orang mati kepada Tuhan dengan manusia yang ada di alam sekitar. Setiap keluarga yang telah melakukan nganjan ini, baru boleh mengadakan acara dirumahnya, jika belum maka tidak boleh ada acara di rumahnya. Seandaianya masih tetap mengadakan acara, maka penduduk sekitar tidak mau hadir, dan yang mengadakan acara mendapatkan hukuman secara adat. Acara ini diadakan selama satu minggu dengan pesta Babi dan tuak/arak sampai mabuk. Prinsip yang ditanamkan bagi masyarakat Dayak Pesaguan dalama pesta adalah makan sampai kenyang dan minum sampai mabuk, kalau tidak maka belum dinamakan pesta.

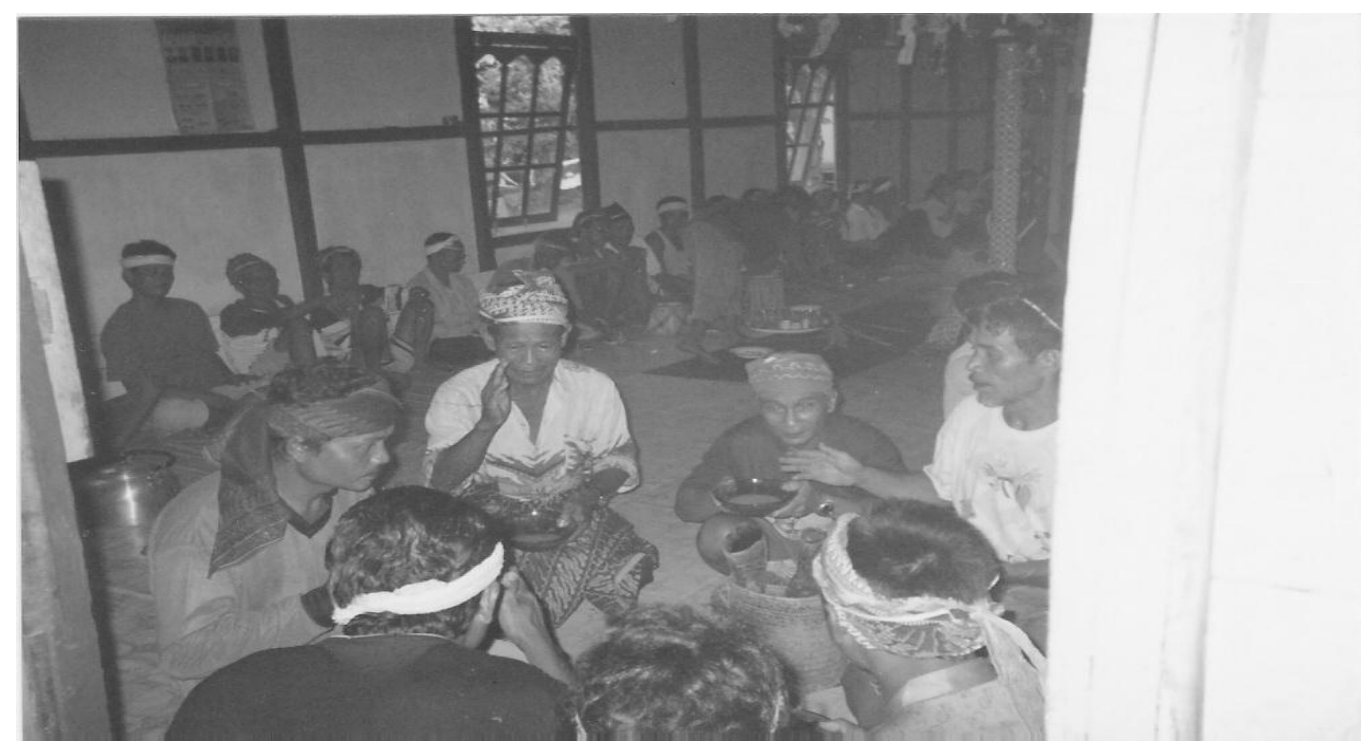

Gambar 1. Adat Nganjan di Beringin (Dokumentasi Hasil Penelitian Lapangan)

\section{Pembahasan}

Bagian pembahasan akan mendeskripsikan kondisi spesifik mengenai Kekristenan. Gambaran deskriptif ini diharapkan dapat didiskusikan pada bagaian ini. Pembahasan akan dimulai dari deskripsi jumlah penduduk dan status kekristenannya. Jumlah Penduduk 
Dayak Pesaguan \pm 10.000 orang. Dari jumlah tersebut, \pm 9.000 orang adalah orang Kristen secara KTP, dan \pm 1.000 orang sudah pindah agama muslim, dan itu bisa bertambah terus.

Lebih lanjut, Belum ada Alkitab yang berbahasa Suku Dayak Pesaguan, kebanyakan mereka mendengarkan Injil dalam bahasa Indonesia saja sedangkan mereka banyak yang belum mengerti bahasa Indonesia dan belum mengerti baca tulis. Belum ada literatur Kristen yang dimiliki Suku Dayak Pesaguan, dan belum ada yang mengembangkannya, karena masyarakat Suku Dayak Pesaguan banyak yang belum mengerti baca dan tulis. Kebanyakan penduduk Dayak Pesaguan memiliki televisi dengan memakai Parabola, akan tetapi mereka menyukai siaran-siaran televisi yang berhubungan dengan ke Islaman. Untuk radio, mereka belum memiliki siaran. Mereka juga lebih senang dengan film duniawi.

Tokoh Kristen yang berpengaruh dalam masyarakat adalah tokoh Katolik dan Protestan, namun sayang banyak diantara mereka yang belum lahir baru. Mereka juga merangkap sebagai pemimpin adat. Belum ada jaringan doa khusus yang dimiliki suku Dayak Pesaguan. Namun mereka memiliki persekutuan hamba-hamba Tuhan se-kecamatan Tumbang Titi, tetapi itu juga hampir tidak jalan karena gereja yang satu dengan lainnya saling bermusuhan dan menganggap diri lebih baik dari gereja lain. Beberapa denominasi gereja yang ada meliputi (1) Katolik; (2) GPIB (Gereja Protestan Indonesia bagian Barat); (3) KGBI (Kerapatan Gereja Baptis Indonesia; (4) GKSI (Gereja Kristen Sepenuh Indonesia); (5) GPDI (Gereja Pantekosta di Indonesia)

Gereja yang ada belum ada yang secara khusus terbuka untuk menjangkau suku Dayak Pesaguan adapun setiap gereja yang ada terbuka dan tidak secara khusus untuk suku dan bukanlah gereja suku tersebut, walaupun pada kenyataannya yang bergereja di setiap gereja yang ada adalah orang suku Dayak Pesaguan, dan sedikit sekali orang yang dari luar suku Dayak Pesaguan. Berdasarkan data yang ditemukan di lapangan, belum ada badan PI Internasonal yang berfokus terhadap Suku Dayak Pesaguan, dulu ada dari Jerman akan tetapi sudah tidak lagi kerena mereka menganggap sudah percaya.

Pada umumnya masyarakat suku Dayak Pesaguan memiliki keterbukaan yang sangat baik, mereka sangat senang menerima orang lain yang bukan dari suku mereka, untuk itu sangatlah penting keterlibatan orang kristen dalam menentukan perkembangan. Sangat disayangkan sedikit sekali orang kristen mau terlibat dalam menentukan perkembangan masyarakat bahkan mereka membedakan antara kehidupan bermasyarakat dan kehidupn bergereja, bahkan ada banyak mempertanyakan peranan penginjilan dan kehidupan sosial, padahal Tuhan Yesus mengajarkan bahwa kita tidak boleh munafik.

Injil sudah lama didengar oleh masyarakat suku Dayak Pesaguan, oleh sebab itu mereka banyak tahu tentang Injil akan tetapi sedikit sekali yang menerapkan Injil dalam kehidupan sehari-hari. Penghalang yang paling berat adalah setiap pemimpin gereja yang ada mengklaim itu ladang pelayanannya dan saling bermusuhan satu dengan yang lain, kebudayaan yang lebih kuat dari agama, dan pendidikan yang terbatas.

Kepercayaan yang dimiliki oleh masyarakat suku Dayak Pesaguan adalah Katolik dan Kristen akan tetapi mereka juga sangat mempercayai adanya kuasa gelap. Dalam hal ini sinkritisme agama masih sangat kuat dalama kepercayaan suku Dayak Pesagauan. Ini jelas menduakan Allah, melanggar perintah dan kehendak Allah, serta menentang Allah, padahal Allah tidak mau diduakan oleh apapun dan siapapun.

Hendaknya setiap orang yang percaya hanya menyebut dan menyembah Dia yang berkuasa dan yang sesuai dengan apa yang dikatakan oleh Alkitab. Segala tindakan dan perilaku suku Dayak Pesaguan diatur oleh hukum adat. Begitu juga dengan kehidupan mereka yang berdasarkan adat yang ada, sehingga adat betul-betul mempengaruhi tatanan cara hidup masyrakat Dayak Pesaguan.

Cara yang tepat dalam masuk dan memberitakan Injil bagi suku Dayak Pesaguan adalah mendekati setiap pemimpin Gereja yang ada, mengubah cara hidup menjadi lebih 
baik melalui keteladan hidup. Selain itu juga menolong masyarakat dayak Pesaguan melalui ilmu pengetahuan yang dapat menolong masyarakat supaya mereka dapat melakukan apa yang seharusnya dilakukan sesuai dengan kemampuan masyarakat suku Dayak Pesaguan. Memang ada beberapa yang tidak bisa dilakukan, akan tetapi dengan ilmu yang dimiliki mereka dapat melakukannya, dan masyarakat Dayak Pesaguan dapat melihat dan mengambil keputusan dengan akal.

\section{Pendekatan yang Tepat}

Ada banyak cara yang dapat digunakan untuk masuk kedalam satu daerah. Salah satu cara diantaranya adalah, kontekstualisasi sebagai cara yang dapat diterima oleh setiap masyarakat yang ada. Masyarakat suku Dayak Pesaguan dapat menerima seorang yang tergerak hatinya untuk masuk dan bersatu dalam lingkungannya, serta mengambangkan apa yang ada dalam lingkungan mereka, seperti kebutuhan kesehatan, pendidikan dan pelatihan terhadap kaum muda.

Penjangkauan suku Dayak Pesaguan dapat dilaksanakan dengan doa, supaya para pemimpin gereja ada kesatuan satu dengan yang lain. Ada orang yang tergerak hatinya untuk menjelaskan kepada mereka Injil yang benar dan menjadi teladan yang baik. Supaya kepercayaan dan kuasa gelap di lingkungan mereka dapat dihancurkan. Kebiasaan mereka mengkonsumsi minuman keras dan obat-obatan terlarang dihilangkan.

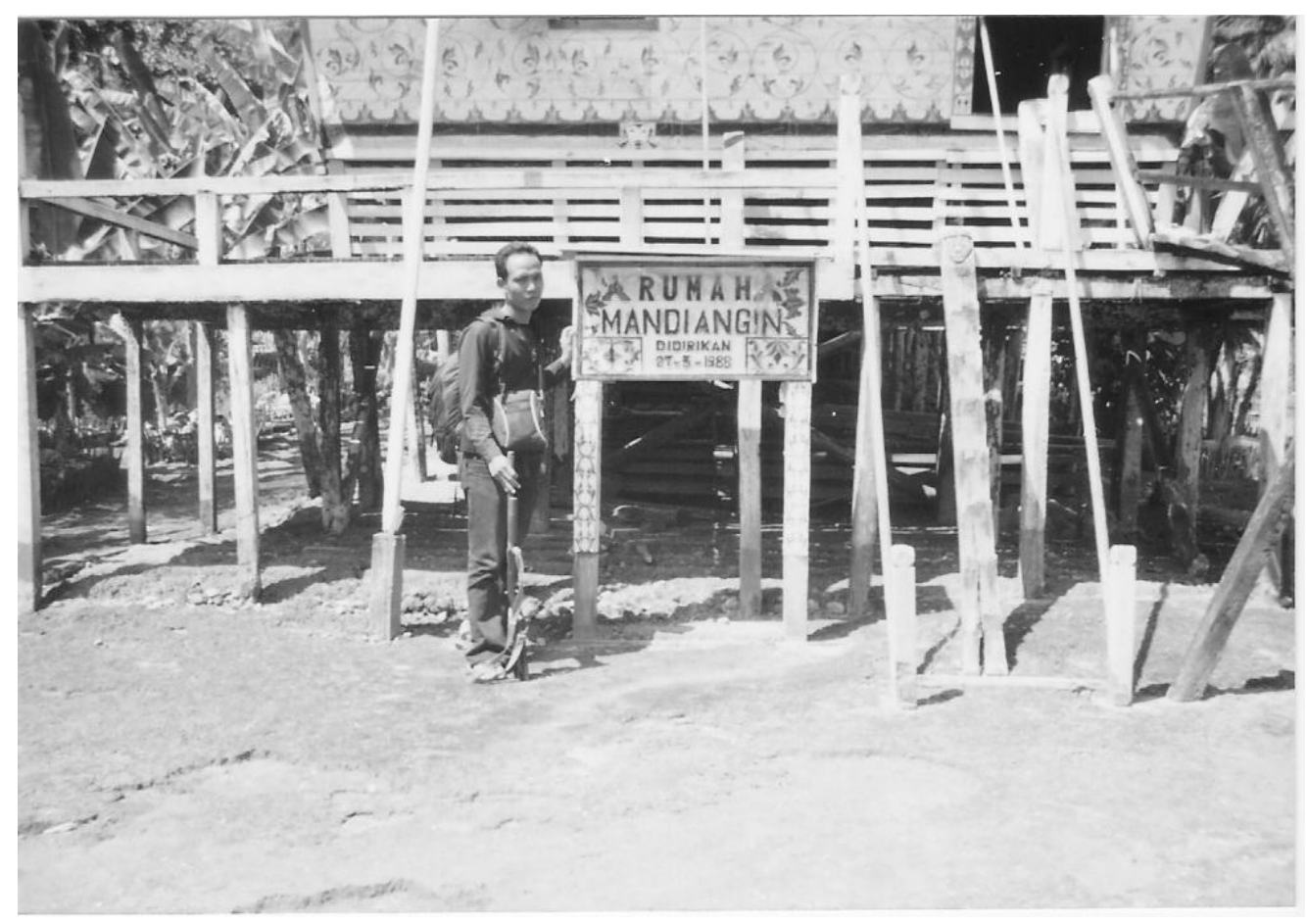

Gambar 2. Rumah Adat Dayak Pesaguan

\section{Implikasi}

Penelitian ini memiliki implikasi terhadap data etnografis Dayak Pesaguan. Pendekatan spesifik dapat disebut etnografis dialogis yang berciri menjemuk dan multikonteks. Dengan ciri pendekatan yang baru diharapkan para peneliti selanjutnya dan atau penelitian lanjutan akan memberikan gambaran etnografis multikonteks yang berguna untuk pendekatan penginjilan ke suku-suku lain di Indonesia. 


\section{Rekomendasi untuk Penelitian Lanjutan}

Rekomendari untuk penelitian selanjutnya haruslah menyentuh berbagai aspek yang lebih spesifik, sebagai contoh budaya dan agama yang dapat dijadikan konsep teologi kentekstual untuk menjangkau suku Dayak Pesaguan. Penelitian-penelitian etnografis lainnya juga dirasa perlu ditingkatkan mengingat beberapa aspek yang belum dijangkau dalam penelitian ini.

\section{Kesimpulan}

Orang Dayak Pesaguan, sebagian besar, menganut agama Katolik dan Protestan. Sangat disayangkan, dalam kehidupan sehari-hari, mereka kurang menerapkan ajaran. Adat istiadat merekalah yang lebih banyak mengatur tatanan hidup bermasyarakat di masyarakat Dayak Pesaguan, seperti minum-minuman keras, pernikahan secara adat, acara-acara ritual, dan kepercayan akan pohon, sungai, dan batu menjadi sebagian contoh yang dimiliki suku Dayak Pesaguan, yang tidak sesuai dengan Alkitab dan bertentangan dengan kehendak dan tujuan Allah menjadikan manusia.

Pemimpin Gereja, Majelis dan para pemimpin Katolik adalah seorang pemimpin agama yang seharusnya menjadi contoh teladan dalam kehidupan Alkitab akan tetapi mereka juga adalah pemimpin adat dan pemegang kebudayaan yang ada dalam masyarakat suku Dayak Pesaguan. Para hamba Tuhan, utusan Injil, Yayasan Kristen, kebanyakan membesarkan nama denominasinya daripada nama Kristus yang seharusnya menjadi junjungan tinggi dan disampaikan kepada masyarakat suku Dayak Pesaguan supaya hidup benar dimata Tuhan.

Tidak ada orang dari suku Dayak Pesaguan menjangkau orang muslim Melayu untuk percaya pada Yesus, padahal orang suku melayu muslim adalah tetangga mereka, bahkan sebaliknya merekalah yang ikut Islam. Beberapa pemuda Kristen Suku Dayak Pesaguan menjadi muslim melalui jalan pernikahan. Jadi, pada akhirnya masyarakat suku Dayak Pesaguan membutuhkan Injil yang benar, supaya dapat membimbing mereka dalam kehidupan yang benar, keluar dari pengaruh kuasa kegelapan dan minuman keras, dan sinkritisme harus dihilangkan bagi masyarakat suku Dayak Pesaguan.

Keterbatasan akan pendidikan dan kesehatan harus menjadi taget utama dalam menjangkau mereka, keteladanan yang baik akan memberi pengaruh positif bagi perkembangan kerohanian suku Dayak Pesaguan. Dalam hitungan angka 90\% suku dayak pesaguan belum lahir baru dan belum mengerti arti Injil apalagi melakukan Injil itu dengan sungguh-sungguh, dan 90\% mereka masih dipengaruhi adat istiadat yang bertentangan dengan Alkitab.

\section{Rujukan}

Darmadi, Hamid. "Sumpit (Blowgun) as Traditional Weapons with Dayak High Protection." JETL (Journal Of Education, Teaching and Learning) 3, no. 1 (2018): 113.

Erwinsyah, Rudy G, Jurusan Antropologi Budaya, Fakultas Ilmu Budaya, and Universitas Gadjah Mada. "Gereja Dan Transformasi Sosial Dalam Masyarakat Dayak Kualatn Di Hulu Sungai Buayan." Rural Economies 1, no. 2 (2010): 1-26.

Hartono, Ferry, Sukawiti Sukawiti, and Herianus Nuryadi. "Idealized Abstraction of the Concept of Human in Dayak Kanayatn's Byword and Its Importance in Dissolving Ethnic Conflicts in West Borneo." Advances in Social Science, Education and Humanities Research, volume 203: International Conference on Life, Innovation, Change, and Knowledge (ICLICK 2018) Idealized 203, no. Iclick 2018 (2019): 62-68.

Herianto, Herianto, Zaenal Kusuma, Ellis Nihayati, and Cahyo Prayogo. “The Plant Wisdom of Dayak Ot Danum, Central Kalimantan." Journal of Tropical Life Science 8, no. 2 
(2018): 130-143.

Iswanto, and Rinto Hasiholan Hutapea. "LEGO-LEGO AS PHENOMENON OF INTERRELIGIOS AND CULTURAL IN ALOR SOCIETY." Harmoni 19, no. 1 (October 28, 2020): 85-99.

http://jurnalharmoni.kemenag.go.id/index.php/harmoni/article/view/361.

Iswanto, and Ferdinand Alexander. "Perspektif Inklusif Pendidikan Agama Kristen Terhadap Teks Kerja Pada Masyarakat Dawan Di Nusa Tengara Timur" 1 (2020): 7184.

Kamil, Ade Ikhsan. "DARI POHON HIDUP KE KAYU MATI Perubahan Pencarian Keselamatan Orang Dayak Dalam Kehidupan Desa Di Kalimantan Barat." Jurnal Sosiologi USK 12, no. 1 (2018): 76-88.

Kusuma Wardani, Laksmi, Ronald Hasudungan Irianto Sitindjak, Poppy F. Nilasari, and Devina Faustine Widjayadi. "Form And Meaning Of Dayak Traditional House In East Kalimantan, Indonesia (Case Study: Lou Pepas Eheng Dayak Benuaq's House)." Advances in Social Science, Education and Humanities Research, volume 207: 3rd International Conference on Creative Media, Design and Technology (REKA 2018) Form 207, no. Reka (2019): 265-272.

Lydahl, Doris, Suvi Holmberg, Kirsi Günther, and Johanna Ranta. "Doing Data Together Affective Relations and Mobile Ethnography in Home Visits." Qualitative Research (2020).

Peters, B. Guy, Guillaume Fontaine, and Raul Pacheco-Vega. "Using Ethnography in Comparative Policy Analysis: Premises, Promises and Perils." Handbook of Research Methods and Applications in Comparative Policy Analysis, no. October (2020): 312-332.

Purwanto, Semiarto. "Questioning the Development: The Maintenance of Local Variety of Rice in the Changing Dayak Community of Central Kalimantan , Indonesia." Advances in Social Science, Education and Humanities Research (ASSEHR), volume 161 :International Conference on Issues in Social and Education Research (ICISER 2017) Questioning 161, no. Iciser 2017 (2018): 22-26.

De Rond, Mark, Isaac Holeman, and Jennifer Howard-Grenville. "Sensemaking from the Body: An Enactive Ethnography of Rowing the Amazon." Academy of Management Journal 62, no. 6 (2019): 1961-1988.

Simanjuntak, Atmaezer Hariara, and Dwi P Sulaksono. "PALM OIL TREE FETISH: A PLANTATION GOD IN THE PROCESS OF CONSTRUCTION IN WEST KALIMANTAN." The 7th International Symposium of Journal Antropologi Indonesia (2019): 145-146.

Simmons, Erica S., and Nicholas Rush Smith. "The Case for Comparative Ethnography." Comparative Politics 51, no. 3 (2019): 341-359.

Wajsberg, Mirjam. "Following Fatigue, Feeling Fatigue: A Reflexive Ethnography of Emotion." Social Inclusion 8, no. 4 (2020): 126-135. 